\title{
Effect of Streptozotocin-Induced Diabetes on the Metabolism of ADP, AMP and Adenosine in the Pulmonary Circulation of Rat Isolated Lung
}

\author{
Y.S. Bakhle and R. Chelliah \\ Department of Pharmacology, Institute of Basic Medical Sciences, Royal College of Surgeons of England, London, UK
}

\begin{abstract}
Summary. The uptake and metabolism of radioactive ADP, AMP and adenosine was investigated in the pulmonary circulation of lungs taken from rats with streptozotocin-induced diabetes. Between 0.26 and $500 \mu \mathrm{mol} / 1 \mathrm{ADP}$ was extensively hydrolysed to AMP equally in control and diabetic lungs. At $1 \mathrm{mmol} / \mathrm{l}$ there was less ADP breakdown in diabetic lungs. Hydrolysis of AMP to adenosine was also less in diabetic lungs at $10 \mu \mathrm{mol} / 1$ and $1 \mathrm{mmol} / 1$ substrate concentration, but adenosine metabolism and uptake at these concentrations was
\end{abstract}

not affected by diabetes. The results indicate that formation of the anti-aggregatory adenosine and, to a lesser extent, breakdown of the pro-aggregatory ADP were decreased in diabetic lungs and may contribute to the platelet hyperreactivity associated with diabetes.

Key words: ADP-ase, adenosine, rat, lung, streptozotocin, diabetes, endothelium.
In diabetes mellitus, platelet aggregation is enhanced [3, $6,7]$ and such hyperactive platelet function may contribute to the aetiology of associated vascular disease. However, platelet function in vivo is influenced by the anti-aggregatory properties of vascular endothelium, one of which is the breakdown of the pro-aggregatory adenosine diphosphate (ADP) released from the platelet by an ADP-ase activity associated with endothelial cells [8]. Another unrelated anti-aggregatory property, synthesis of prostacyclin, has already been shown to be decreased in the pulmonary circulation of isolated lungs from diabetic rats [15].

We have therefore undertaken an investigation of the metabolism of ADP, AMP and adenosine in the pulmonary circulation of lungs from rats made diabetic by streptozotocin.

\section{Materials and Methods}

\section{Preparation of Diabetic Rats}

Male Wistar rats $(130-150 \mathrm{~g}$ body weight) were made diabetic by a single IP injection of streptozotocin $(85 \mathrm{mg} / \mathrm{kg})$ prepared in a salinecitrate buffer $(0.9 \% \mathrm{NaCl} \mathrm{w} / \mathrm{v}$ and $0.1 \mathrm{mmol} / 1$ citrate, $\mathrm{pH} 4)$. Sex and age-matched control rats received an injection of the saline-buffer at the same time. Twenty days after treatment, blood glucose in the diabetic rats was found to be $30.3 \pm 0.6 \mathrm{mmol} / 1(n=6)$ compared with
$8.6 \pm 0.5 \mathrm{mmol} / \mathrm{l}$ in the control animals $(n=6)$ and this higher glucose level was maintained for up to 60 days. Animals were used between 25 and 50 days after treatment.

\section{Preparation of Lungs}

Animals were anaesthetised by IP injection of sodium pentobarbitone $(60 \mathrm{mg} / \mathrm{kg})$. The lungs were removed and perfused via the pulmonary artery as described previously [1] with oxygenated $\left(95 \% \mathrm{O}_{2}: 5 \% \mathrm{CO}_{2}\right)$ Krebs solution (mmol/l: $\mathrm{NaHCO}_{3}, 25 ; \mathrm{NaCl}, 120 ; \mathrm{KCl}, 4.7 ; \mathrm{CaCl}_{2}, 2.5$; $\mathrm{KH}_{2} \mathrm{PO}_{4}, 1.2 ; \mathrm{MgSO}_{4}, 1.2$; glucose, 5.6) at $37^{\circ} \mathrm{C}$ and a constant flow rate of $8 \mathrm{ml} / \mathrm{min}$.

\section{Infusion of Radiolabelled Substrates}

After an initial 10-min period of perfusion to clear the lung of blood and to allow for equilibration, radiolabelled ${ }^{14} \mathrm{C}$ or ${ }^{3} \mathrm{H}$-ADP, AMP or adenosine $\left(0.665 \mu \mathrm{Ci}\right.$ of ${ }^{14} \mathrm{C}$ or $6.65 \mu \mathrm{Ci}$ of ${ }^{3} \mathrm{H}$ per infusion) together with varying amounts of unlabelled substrate were infused at a rate of $0.8 \mathrm{ml} / \mathrm{min}$ for $10 \mathrm{~s}$ through the pulmonary arterial cannula. Lung effluent was collected during and after this infusion either to measure total radioactivity (efflux) or for analysis by thin layer chromatography as described below.

\section{Efflux of Radioactivity}

In these experiments lung effluent was collected in $15 \mathrm{~s}$ fractions for the first $2 \mathrm{~min}$. Samples $(1 \mathrm{ml})$ of each fraction were mixed with $10 \mathrm{ml}$ Triton-toluene scintillant $(25 \mathrm{~g}$ PPO $+1.25 \mathrm{~g}$ dimethyl POPOP +5 litres toluene +2.5 litres Triton $\mathrm{X}-100$ ) and the radioactivity measured. 
Table 1. Analysis of effluent radioactivity following ADP infusions to isolated lungs from control and diabetic rats

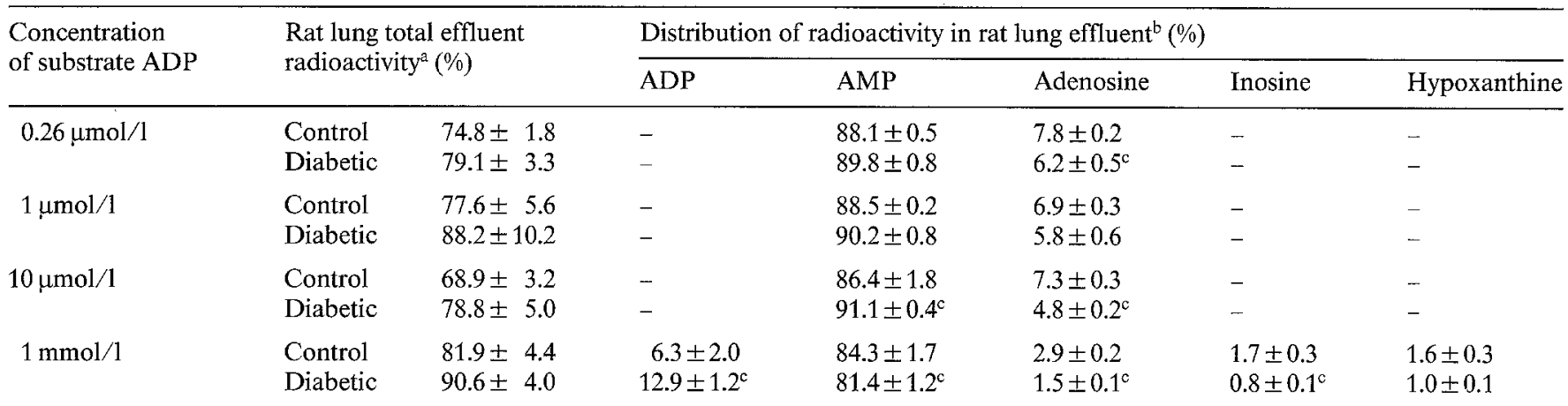

Results are expressed as mean \pm SEM of five lungs. ${ }^{a}$ Total radioactivity collected in the 1-min fraction and expressed as a percentage of the total infused; ${ }^{b}$ Results are expressed as a percentage of total effluent radioactivity. Where no value is given $<1 \%$ of the effluent radioactivity was associated with that material; ${ }^{\mathrm{c}}$ Significantly different from value in control rats $(2 p<0.05)$

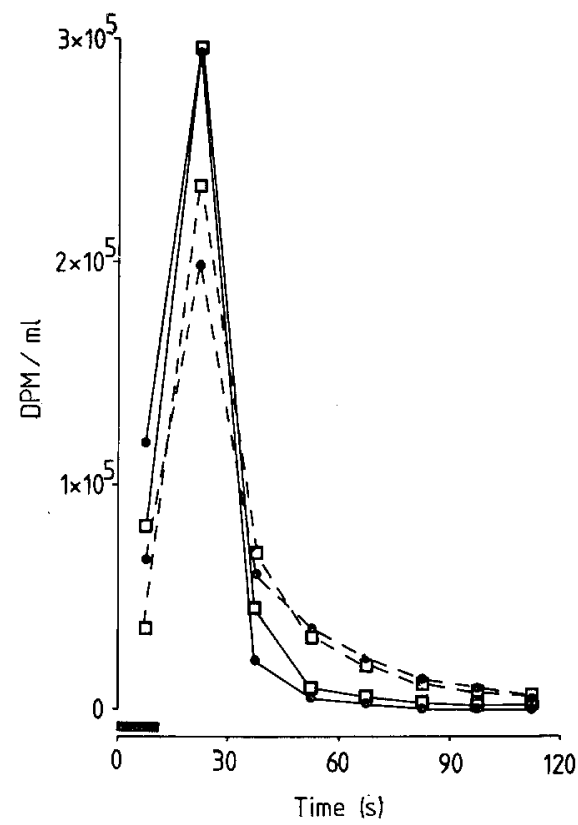

Fig.1. Efflux of radioactivity from isolated rat lung following infusion of ${ }^{14} \mathrm{C}$-ADP $(10 \mu \mathrm{mol} / 1$; solid lines $)$ or ${ }^{3} \mathrm{H}$ adenosine $(10 \mu \mathrm{mol} / 1$; broken lines). The infusion period (10s) is marked by the black bar. For either substrate, efflux from control lungs $(-)$ was not different from that from diabetic lungs ( $\square$ ), although the efflux of ${ }^{14} \mathrm{C}$ (from ADP) was faster than that of ${ }^{3} \mathrm{H}$ (from adenosine). The values shown are the mean results ( $n=3$, ADP; $n=2$, adenosine) of the radioactivity (as disintegrations/min: DPM) per ml of effluent collected in $15 \mathrm{~s}$ fractions

\section{Analysis of Lung Effluent}

Lung effluent was collected in a single $(60 \mathrm{~s})$ fraction during and after the infusion of radiolabelled substrate. The $60 \mathrm{~s}$ effluent fraction was acidified to $\mathrm{pH} 3.5$ with $10 \% \mathrm{HClO}_{4}$ and aliquots $(20 \mu \mathrm{l})$ applied to plastic-backed silica gel plates containing a fluorescent indicator for analysis by thin layer chromatography. A mixture of marker ATP, ADP, AMP, inosine monophosphate (IMP), inosine, adenosine, hypoxanthine and adenine, was applied to the plates which were developed in one of two solvent systems. System I was isobutyl alcohol/amyl alcohol/ethylene glycol monoethyl ether/ammonia/water, $45: 30: 90: 45: 60$ [10]. Typical $\mathbf{R}_{\mathrm{f}}$ values obtained with a solvent front height of $10 \mathrm{~cm}$ were: ATP, 0.15; ADP, 0.32; IMP, 0.39; AMP, 0.48; inosine, 0.64; adenosine + hypoxanthine, 0.75; adenine, 0.84. Better separation of nucleosides and bases was provided by solvent system II: n-butanol/ethyl acetate/methanol/ammonia, 7:4:3:4 [13]. In this solvent system the nucleotides ATP, ADP, AMP and IMP remained at or near the origin while the nucleosides were better resolved with typical $R_{f}$ values (for $14 \mathrm{~cm}$ solvent front height) of: inosine, 0.26; hypoxanthine, 0.46; adenosine, 0.57; adenine, 0.64. All samples were analysed in both solvent systems unless otherwise stated.

Standards were visualised under ultraviolet light and quenched purine areas were marked, cut out and transferred to scintillation vials. The purines were eluted with distilled water $(1 \mathrm{ml})$ for $1 \mathrm{~h}$, Triton-toluene scintillant $(10 \mathrm{ml})$ was added and the radioactivity counted in a liquid scintillation counter. Over $90 \%$ of the radioactivity applied was recovered from the plates.

Lung uptake: Immediately following substrate infusion and effluent collection, lungs were taken down from the perfusion system, dissected free of the trachea, the remainder of the heart and any extraneous tissue, weighed and homogenised in cold $10 \%(\mathrm{w} / \mathrm{v})$ trichloroacetic acid (lung weight to volume ratio, 1:10). The homogenate was centrifuged at $1,000 \times \mathrm{g}$ for $20 \mathrm{~min}$ and the radioactivity counted in aliquots of the supernatant $(20 \mu \mathrm{l})$. Lung supernatants from adenosine experiments were adjusted to $\mathrm{pH} 5.5$ with $5 \mathrm{~mol} / 1-\mathrm{K}_{2} \mathrm{CO}_{3}$ and samples $(20 \mu l)$ analysed by thin layer chromatography as described above. To check for breakdown of substrate during the extraction process, ${ }^{3} \mathrm{H}$ ADP, -AMP, -ATP and -adenosine were added separately to perfused lungs immediately before homogenisation in trichloroacetic acid and the extraction and analysis carried out as usual. The tested compounds were stable during this procedure, $>93 \%$ of each remaining as unchanged substrate after extraction and analysis.

\section{Incubation of ADP with Lung Effluent}

Samples of lung effluent were collected after the initial 10-min period of perfusion. Lung effluent $(1 \mathrm{ml})$ was incubated with ${ }^{3} \mathrm{H}$-ADP $(100 \mu \mathrm{l}, 0.5 \mu \mathrm{Ci}$, final concentration of $10 \mu \mathrm{mol} / 1$ or $1 \mathrm{mmol} / \mathrm{l})$ in a shaking water bath at $37^{\circ} \mathrm{C}$. Aliquots $(200 \mu \mathrm{l})$ were taken immediately on addition of the substrate and at hourly intervals for up to $4 \mathrm{~h}$. Each aliquot was adjusted to $\mathrm{pH} 3.5$ with cold $\mathrm{HClO}_{4}(2.5 \%)$ before analysis by thin layer chromatography in solvent I as described above. Protein in the effluents was estimated by the method described by Mejbaum-Katzenellenbogen and Dobryszycka [9].

\section{Materials}

Sodium pentobarbitone (Sagatal) was purchased from May \& Baker, Dagenham, UK. The following compounds were purchased from Sigma, Poole, UK: streptozotocin; diagnostic kit for blood glucose deter- 
Table 2. Analysis of reaction mixtures after incubation of ${ }^{14} \mathrm{C}$-ADP with effluent from control and diabetic rat lungs

\begin{tabular}{|c|c|c|c|c|c|}
\hline \multirow{3}{*}{$\begin{array}{l}\text { Time of } \\
\text { incubation } \\
\text { (h) }\end{array}$} & \multirow{3}{*}{ Mixture } & \multicolumn{4}{|c|}{ Composition of mixture } \\
\hline & & \multicolumn{2}{|c|}{$10 \mu \mathrm{mol} / 1^{b}$} & \multicolumn{2}{|l|}{$1 \mathrm{mmol} / \mathrm{1}^{\mathrm{b}}$} \\
\hline & & Control & Diabetic & Control & Diabetic \\
\hline 0 & $\begin{array}{l}\text { ADP } \\
\text { AMP } \\
\text { Adenosine }\end{array}$ & $\begin{array}{c}95.8 \pm 0.4 \\
1.9 \pm 0.1 \\
-\end{array}$ & $\begin{array}{c}96.6 \pm 0.6 \\
1.8 \pm 0.3 \\
-\end{array}$ & $\begin{array}{r}97.4 \pm 0.5 \\
0.8 \pm 0.1 \\
-\end{array}$ & $\begin{array}{c}97.4 \pm 0.3 \\
0.7 \pm 0.1 \\
-\end{array}$ \\
\hline 1 & $\begin{array}{l}\text { ADP } \\
\text { AMP } \\
\text { Adenosine }\end{array}$ & $\begin{array}{r}61.8 \pm 4.4 \\
30.7 \pm 4.1 \\
3.9 \pm 0.5\end{array}$ & $\begin{array}{r}69.3 \pm 3.0 \\
26.2 \pm 3.1 \\
1.6 \pm 0.5\end{array}$ & $\begin{array}{c}68.4 \pm 1.0 \\
16.6 \pm 0.4 \\
-\end{array}$ & $\begin{array}{r}84.7 \pm 0.3^{c} \\
8.2 \pm 0.2^{c} \\
-\end{array}$ \\
\hline 2 & $\begin{array}{l}\text { ADP } \\
\text { AMP } \\
\text { Adenosine }\end{array}$ & $\begin{array}{l}41.5 \pm 5.7 \\
41.8 \pm 4.8 \\
12.3 \pm 1.1\end{array}$ & $\begin{array}{c}51.0 \pm 4.3 \\
39.9 \pm 4.3 \\
5.7 \pm 0.4^{c}\end{array}$ & $\begin{array}{c}50.0 \pm 0.8 \\
27.6 \pm 0.7 \\
-\end{array}$ & $\begin{array}{c}72.6 \pm 0.4^{c} \\
15.5 \pm 0.4^{c} \\
-\end{array}$ \\
\hline 3 & $\begin{array}{l}\text { ADP } \\
\text { AMP } \\
\text { Adenosine }\end{array}$ & $\begin{array}{l}29.7 \pm 5.0 \\
41.8 \pm 4.0 \\
23.3 \pm 1.6\end{array}$ & $\begin{array}{l}38.6 \pm 4.7 \\
46.1 \pm 4.6 \\
11.4 \pm 0.8^{\mathrm{c}}\end{array}$ & $\begin{array}{c}40.0 \pm 0.7 \\
34.9 \pm 1.0 \\
-\end{array}$ & $\begin{array}{c}63.7 \pm 0.4^{c} \\
21.7 \pm 0.5^{c} \\
-\end{array}$ \\
\hline 4 & $\begin{array}{l}\text { ADP } \\
\text { AMP } \\
\text { Adenosine }\end{array}$ & $\begin{array}{l}19.8 \pm 4.3 \\
36.4 \pm 3.3 \\
37.9 \pm 2.8\end{array}$ & $\begin{array}{l}29.0 \pm 4.7 \\
47.0 \pm 4.4 \\
18.5 \pm 0.5^{\mathrm{c}}\end{array}$ & $\begin{array}{c}35.2 \pm 0.5 \\
40.2 \pm 1.3\end{array}$ & $\begin{array}{c}57.5 \pm 0.8^{c} \\
26.8 \pm 0.4^{c}\end{array}$ \\
\hline
\end{tabular}

${ }^{2}$ Composition is expressed as the percentage of the total ${ }^{14} \mathrm{C}$ in the reaction mixture associated with the compounds shown; ${ }^{b}$ Initial substrate concentration of ADP; ${ }^{c}$ Significantly different from control value $(2 p<0.05)$. Results are expressed as mean \pm SEM of three lungs. The incubation mixtures were analysed at the times shown by thin layer chromatography using solvent system I. Where no value is given $<1 \%$ of total radioactivity was associated with that component

Table 3. Analysis of effluent radioactivity following AMP infusions to isolated lungs from control and diabetic rats

\begin{tabular}{|c|c|c|c|c|}
\hline \multirow{2}{*}{$\begin{array}{l}\text { Concentration } \\
\text { of substrate } \\
\text { AMP }\end{array}$} & \multirow{2}{*}{$\begin{array}{l}\text { Total } \\
\text { effluent } \\
\text { radioac- } \\
\text { tivity }(\%)\end{array}$} & \multicolumn{3}{|c|}{$\begin{array}{l}\text { Distribution of radioactivity in effluent } \\
(\%)\end{array}$} \\
\hline & & AMP & Adenosine & Hypoxanthine \\
\hline \multicolumn{5}{|l|}{$1 \mu \mathrm{mol} / 1$} \\
\hline Control & $70.3 \pm 4.7$ & $87.1 \pm 1.1$ & $7.3 \pm 0.7$ & - \\
\hline Diabetic & $73.3 \pm 3.5$ & $88.7 \pm 0.4$ & $6.7 \pm 0.4$ & - \\
\hline \multicolumn{5}{|l|}{$10 \mu \mathrm{mol} / 1$} \\
\hline Control & $72.0 \pm 3.2$ & $89.2 \pm 0.4$ & $6.9 \pm 0.2$ & - \\
\hline Diabetic & $71.8 \pm 2.4$ & $91.9 \pm 0.4^{\mathrm{a}}$ & $4.1 \pm 0.4^{\mathrm{a}}$ & - \\
\hline \multicolumn{5}{|l|}{$1 \mathrm{mmol} / \mathrm{l}$} \\
\hline Control & $90.5 \pm 2.1$ & $92.8 \pm 0.7$ & $1.8 \pm 0.2$ & $1.3 \pm 0.2$ \\
\hline Diabetic & $83.5 \pm 2.9$ & $94.9 \pm 0.5$ & $1.3 \pm 0.1^{\mathrm{a}}$ & $0.6 \pm 0.2^{\mathrm{a}}$ \\
\hline
\end{tabular}

Results are expressed as the mean \pm SEM of five lungs, as analysed by thin layer chromatography. Inosine is omitted from this Table as $<1 \%$ of effluent radioactivity was associated with this material at all concentrations. ${ }^{\text {a }}$ Significantly different from value in control rats $(2 p<0.05)$

mination (colorimetric); adenosine $5^{\prime}$-diphosphate sodium salt; adenosine 5'-monophosphoric acid sodium salt; adenosine $5^{\prime}$-triphosphate disodium salt; inosine $5^{\prime}$-monophosphoric acid sodium salt; adenosine; adenine, inosine, hypoxanthine. The following radiolabelled compounds were purchased from the Radiochemical Centre, Amersham, Bucks, UK; $2-{ }^{3} \mathrm{H}$ adenosine $5{ }^{\prime}$-monophosphate ammonium salt $(19.3 \mathrm{Ci} / \mathrm{mmol}) ; 2{ }^{3} \mathrm{H}$ adenosine $5^{\prime}$-diphosphate ammonium salt $(19.3 \mathrm{Ci} / \mathrm{mmol}) ; 8{ }^{14} \mathrm{C}$ adenosine $5^{\prime}$-diphosphate ammonium salt $(56 \mathrm{mCi} / \mathrm{mmol}) ; 2 .{ }^{3} \mathrm{H}$ adenosine $(21 \mathrm{Ci} / \mathrm{mmol})$. All solvents used were of analytical grade and purchased from British Drug House Chemicals, Dagenham, UK. Plastic-backed thin layer chromatography plates of silica gel with fluorescent indicator $(20 \mathrm{~cm} \times 20 \mathrm{~cm})$ were also obtained from British Drug House Chemicals, Dagenham, UK.

\section{Statistical Methods}

Results are given as mean \pm SEM from the number of experiments shown, each experiment representing a different lung. The statistical significance of the difference between mean values was estimated by Student's t-test for unpaired samples and a value of $2 p<0.05$ was taken as indicating a significant difference.

\section{Results}

\section{Breakdown of $A D P$}

Following infusions of radioactive ADP, the majority of the radioactivity was recovered in lung effluent very rapidly. By $1 \mathrm{~min}$, the radioactivity had fallen to $\sim 1 \%$ of its peak value in lungs from control rats and this efflux was not different in lungs from diabetic rats (Fig. 1). Although the proportion of infused radioactivity in the standard 1 min collection period (Table 1 ) tended to increase with the concentration of ADP infused, at each concentration the values for control and diabetic lungs were not different. Analysis of the effluent radioactivity showed that breakdown of ADP was extensive, i. e. survival was low, over the range of concentrations tested. Only at the highest substrate concentration was survival of ADP $>1 \%$ and a difference between control and diabetic lungs observed (Table 1). At three intermediate concentrations $(30,100$ and $500 \mu \mathrm{mol} / 1 \mathrm{ADP})$ survival of ADP was the same in both sets of lungs (results not shown). At these concentrations and at those shown in Table 1, the major product was AMP, always comprising $>80 \%$ of the effluent radioactivity from either control or diabetic lungs. The only other major metabolite was adenosine and its formation was always less in diabetic than in control lungs (Table 1 ).

The short-term effects of streptozotocin treatment on ADP metabolism were measured in a group of animals $6-8 \mathrm{~h}$ after the injection of streptozotocin. At this time, ADP breakdown at either $10 \mu \mathrm{mol} / 1$ or $1 \mathrm{mmol} / 1$ was the same in treated and control animals. Thus at the lower concentration, the effluent contained $89.3 \pm 0.3 \%$ AMP in control lungs and $88.3 \pm 0.7 \%$ AMP in treated lungs: the proportion of adenosine was $6.6 \pm 0.4 \%$ in control versus $7.6 \pm 0.4 \%$ in treated lungs ( $n=4$ in each case). At the higher concentration, ADP survival was $5.0 \pm 0.5 \%$ (control) and $4.0 \pm 0.5 \%$ (treated) with no difference in the other products of the lung effluent.

In a previous unpublished study, we have shown nucleotidase activity to be present in lung effluent itself, i. e. in perfusate which had passed through the lung. We therefore incubated, for up to $4 \mathrm{~h}$, two concentrations of ADP ( $10 \mu \mathrm{mol} / 1$ and $1 \mathrm{mmol} / \mathrm{l})$ with effluent collected from control and diabetic lungs and analysed the incubation mixture at hourly intervals. As shown in Table 2, at the lower concentration, the proportions of ADP and AMP in the two sets of incubations were similar over the 4-h period. However, there was relatively less adenosine in the incubation mixture from diabetic lung ef- 
Table 4. Analysis of effluent radioactivity following ${ }^{3} \mathrm{H}$-adenosine infusions to isolated lungs from control and diabetic rats

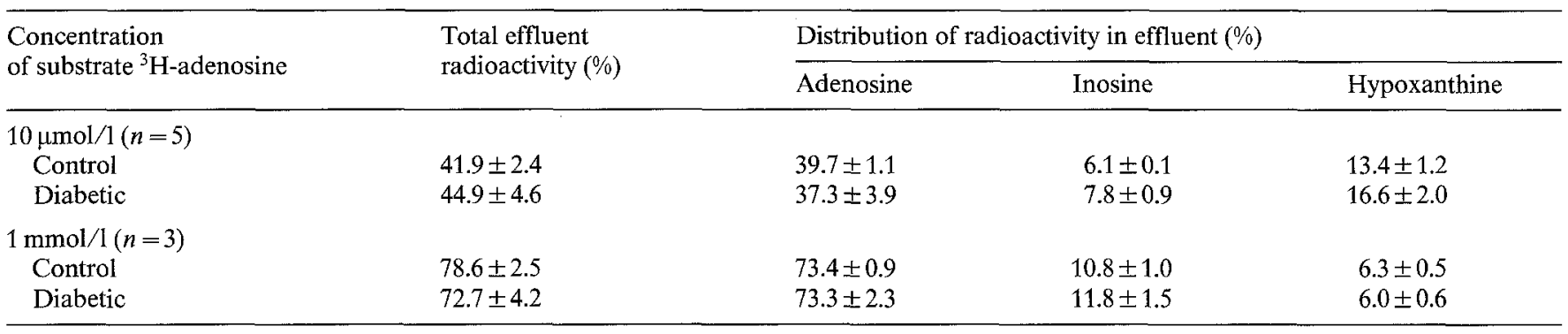

Results are expressed as mean $\pm \mathrm{SEM}$ of the corresponding number of lungs shown in parentheses

Table 5. Analysis of radioactivity retained in lung $1 \mathrm{~min}$ after infusion of ${ }^{3} \mathrm{H}$-adenosine $(10 \mu \mathrm{mol} / \mathrm{l})$ in control and diabetic rats

\begin{tabular}{|c|c|c|c|c|c|}
\hline & \multirow{2}{*}{$\begin{array}{l}\text { Total } \\
\text { retained } \\
\text { radioac- } \\
\text { tivity }(\%)\end{array}$} & \multicolumn{4}{|c|}{$\begin{array}{l}\text { Distribution of retained radioactivity } \\
(\%)\end{array}$} \\
\hline & & ATP & $\mathrm{ADP}$ & IMP & $\mathrm{AMP}$ \\
\hline $\begin{array}{l}\text { Control rats } \\
(n=5) \\
\text { Diabetic rats }\end{array}$ & $43.3 \pm 1.5$ & $85.3 \pm 1.1$ & $7.3 \pm 0.3$ & $1.6 \pm 0.1$ & $2.6 \pm 0.3$ \\
\hline$(n=5)$ & $37.9 \pm 3.8$ & $86.5 \pm 0.4$ & $6.6 \pm 0.3$ & $1.6 \pm 0.1$ & $2.3 \pm 0.3$ \\
\hline
\end{tabular}

Results are expressed as mean \pm SEM of the number of lungs shown in parentheses

fluent than in the control incubation at all times. At the higher substrate concentration $(1 \mathrm{mmol} / \mathrm{l})$ there was a marked increase in ADP survival in diabetic lung effluent compared with control lung effluent and this was accompanied by a decrease in AMP content. No measurable amounts (i. e. $<1 \%$ of the total radioactivity) of adenosine were found at the higher concentration in either control or diabetic lung effluent samples. The protein content of control lung effluent $(82 \pm 22 \mu \mathrm{g} / \mathrm{ml})$ was not significantly different from that of effluent from diabetic lungs $(68 \pm 28 \mu \mathrm{g} / \mathrm{ml})$.

\section{Breakdown of AMP}

Using infusions of AMP, we confirmed directly the high survival of this nucleotide on passage through the pulmonary circulations and were able to demonstrate greater survival, at $10 \mu \mathrm{mol} / 1$ and $1 \mathrm{mmol} / 1$ in diabetic lungs (Table 3 ). This greater survival of substrate was accompanied by decreases in adenosine formation and, at $1 \mathrm{mmol} / \mathrm{l}$, also in the formation of hypoxanthine.

\section{Adenosine Metabolism}

Although the appearance of radioactivity in lung effluent following infusion of ${ }^{3} \mathrm{H}$-adenosine was slower than that after ADP infusions, this efflux of radioactivity was not altered in lungs from diabetic rats (Fig. 1). Analysis of effluent radioactivity (Table 4) showed that although the proportion in the $1 \mathrm{~min}$ fraction increased with in- creasing concentration from $10 \mu \mathrm{mol} / 1$ to $1 \mathrm{mmol} / 1$, this effect was observed equally in control and diabetic lungs. The distribution of effluent radioactivity between the different metabolites was similar in both sets of lungs, unchanged adenosine comprising the major proportion, about one-third at $10 \mu \mathrm{mol} / 1$ and almost threequarters at $1 \mathrm{mmol} / \mathrm{l}$. Radioactivity retained by lung (Table 5) was also similarly distributed in both sets of lungs, predominantly as ATP. This analysis was performed only after the $10 \mu \mathrm{mol} / \mathrm{l}$ infusion of adenosine as the amount of radioactivity retained in lung after $1 \mathrm{mmol} / 1$ adenosine was too low.

\section{Discussion}

We set out to investigate the effect of diabetes on the fate of adenine nucleotides and adenosine in the pulmonary circulation of rat lungs, because the ADP-ase activity of vascular endothelium could be a component of the endothelial anti-aggregatory system [8] and a hyper-aggregable state is well recognized in diabetes [3]. There are, in fact, at least three ways in which endothelium could modify platelet behaviour, which are relevant here. Firstly, the breakdown and, thus, inactivation of pro-aggregatory ADP released from aggregating platelets; secondly, the formation, by hydrolysis of AMP produced via ADP-ase, of anti-aggregatory adenosine, and thirdly, the removal of adenosine by uptake into endothelium $[4,5,11,12]$. The first two reactions would have anti-aggregatory effects and the third, by diminishing the anti-aggregatory factors in the vascular space, a pro-aggregatory effect. Thus, to produce the maximal increase of pro-aggregatory factors, we might expect a decrease in ADP-ase and AMP-ase activities and an increase in adenosine uptake.

We observed a decrease in ADP-ase activity only at the highest concentration $(1 \mathrm{mmol} / 1)$, where survival of ADP was doubled in diabetic lungs compared with that in control lungs. This high concentration of substrate is unlikely to be encountered in blood even in pathological conditions. It is nevertheless worth pointing out that in the micro-environment of platelets aggregating close to the endothelium, higher concentrations might 
be attained than those in the bulk flow of blood. The relative lack of ADP-ase in diabetic lungs was more obvious in the experiments carried out with lung effluent.

With regard to AMP-ase activity, rat perfused lung was relatively deficient in this enzyme as shown by the very high survival of AMP either when produced from ADP or given directly. In spite of this deficiency, the breakdown of AMP in lungs from diabetic rats was always lower than in controls, less adenosine being formed either from ADP or from AMP. This effect was observed at concentrations $<1 \mathrm{mmol} / 1$ and would thus be more likely to be of importance in vivo. It is relevant to note that in human isolated lung, AMP-ase activity is much higher, survival of AMP being only 12\% [2] and thus a decreased AMP-ase activity in lungs of diabetic patients might play a proportionately larger role in controlling platelet function.

We have used the perfused lung in our studies, not because pulmonary thrombosis is particularly associated with diabetes, but because the pulmonary circulation offers a convenient preparation of vascular endothelium to study in situ. Two of the endothelium's enzymic activities, ADP-ase and AMP-ase [5, 12] were decreased in diabetic lungs. This decrease could be due to a lack of enzymic activity, i. e. altered cell membrane or to a lack of endothelium, i. e. less cells. We favour the former explanation as neither adenosine uptake (Table 5) nor the metabolism of 5-hydroxytryptamine, another endothelial cell activity [14], was decreased in streptozotocintreated animals (Bakhle and Chelliah, unpublished data). Furthermore, no immediate cytotoxic effect of streptozotocin on ADP metabolism was observed in lungs $6-8 \mathrm{~h}$ after treatment.

Although the magnitude of the change induced by diabetes is small, it is a change in the direction predicted and compatible with the changes in platelet behaviour [3]. This result taken together with the reduction in prostacyclin synthesis in diabetic lung [15] and other tissues [6] suggests that the hyper-aggregable state associated with diabetes is not solely due to hyper-reactivity of platelets [7] but also reflects a loss of the normal antiaggregatory properties of endothelium. Such a conclusion would emphasise that the biochemical properties of the blood vessel wall are essential components of the factors controlling platelet behaviour in diabetes.

Acknowledgements. We are grateful to the Wellcome Trust for their financial support of this work and of one of us (RC).

\section{References}

1. Alabaster VA, Bakhle YS (1970) Removal of 5-hydroxytryptamine in the pulmonary circulation of rat isolated lungs. $\mathrm{Br} \mathrm{J}$ Pharmacol 40: 468-482

2. Bakhle YS, Chelliah R (1983) Metabolism of adenine nucleotides and adenosine in the pulmonary circulation of isolated lungs from man and other animals. J Physiol 336: $42 \mathrm{P}$

3. Bern MD (1978) Platelet functions in diabetes mellitus. Diabetes 27: $342-352$

4. Crutchley DJ, Ryan US, Ryan JW (1980) Effects of aspirin and dipyridamole on the degradation of adenosine diphosphate by cultured cells derived from bovine pulmonary artery. $\mathbf{J}$ Clin Invest 66: 29-35

5. Dieterle Y, Ody C, Ehrensberger A, Stalder H, Junod AF (1978) Metabolism and uptake of adenosine triphosphate and adenosine by porcine aortic and pulmonary endothelial cells and fibroblasts in culture. Circ Res 42: 869-876

6. Johnson M, Harrison HE, Hawker R, Hawker L (1979) Platelet abnormalities in experimental diabetes. Thromb Haemostasis 42: 333 (Abstract)

7. Lagarde M, Burtin M, Berciaud P, Blanc M, Velardo B, Dechavanne $M$ (1980) Increase of platelet thromboxane $A_{2}$ formation and of its plasmatic half-life in diabetes mellitus. Thromb Res 19: $823-830$

8. Lieberman GE, Lewis GP, Peters TJ (1977) A membrane-bound enzyme in rabbit aorta capable of inhibiting adenosine diphosphate induced platelet aggregation. Lancet $2: 330-332$

9. Mejbaum-Katzenellenbogen W, Dobryszycka WM (1959) Microtannin turbidity assay for protein. Clin Chim Acta 4: 513-522

10. Norman GA, Follet MJ, Hector DA (1974) Quantitative thin layer chromatography of ATP and its degradation products in meat tissue. J Chromatogr 90: 105-111

11. Pearson JD, Carleton JS, Hutchings A, Gordon JL (1978) Uptake and metabolism of adenosine by pig aortic endothelial and smooth-muscle cells in culture. Biochem J 170: 265-271

12. Pearson JD, Carleton JS, Gordon JL (1980) Metabolism of adenine nucleotides by ectoenzymes of vascular endothelial and smooth-muscle cells. Biochem J 190: 421-429

13. Shimizu H, Creveling CR, Daly J (1970) Stimulated formation of adenosine $3^{\prime} 5^{\prime}$ cyclic phosphate in cerebral cortex: synergism between electrical activity and biogenic amines. Proc Natl Acad Sci USA 65: 1035-1040

14. Strum JM, Junod AF (1972) Radioautographic demonstration of 5-hydroxytryptamine ${ }^{3} \mathrm{H}$ uptake by pulmonary endothelial cells. $\mathrm{J}$ Cell Biol 54: 456-467

15. Watts IS, Zakrzewski JT, Bakhle YS (1982) Altered prostaglandin synthesis in isolated lungs of rats with streptozotocin-induced diabetes. Thromb Res 28: 333-342

Received: 23 September 1982

and in revised form: 19 January 1983

Dr. Y.S. Bakhle

Department of Pharmacology

Institute of Basic Medical Sciences

Royal College of Surgeons

Lincoln's Inn Fields

London WC2A 3PN, UK 